\title{
Filamentous sulfur-oxidizing bacteria of the genus Thioploca from Lake Tonle Sap in Cambodia
}

\author{
Fumiko Nemoto ${ }^{1}$, Hisaya Kojima ${ }^{1, *}$, Akifumi Ohtaka ${ }^{2}$, Manabu Fukui ${ }^{1}$ \\ ${ }^{1}$ The Institute of Low Temperature Science, Hokkaido University, Kita-19, Nishi-8, Kita-ku, Sapporo 060-0819, Japan \\ ${ }^{2}$ Faculty of Education, Hirosaki University, 1-Bunkyocho, Hirosaki, Aomori 036-8560, Japan
}

\begin{abstract}
Members of the genus Thioploca are uncultured filamentous sulfur-oxidizing bacteria that live in freshwater/brackish sediments and have the ability to store nitrate in high concentrations in their cells. Their close relatives that inhabit marine sediments, such as Thiomargarita and 'Candidatus Marithioploca', are thought to greatly influence cycles of sulfur, nitrogen, and phosphorus. To date, the genus Thioploca has been reported only from temperate and subarctic areas. Our demonstration of Thioploca in Lake Tonle Sap, Cambodia, is the first report of this genus in a tropical lake. The filaments obtained from Lake Tonle Sap were morphologically similar to those of other lakes. Phylogenetic analysis based on genes for 16S rRNA, 23S rRNA, and the 16S-23S rRNA internal transcribed spacer (ITS) region revealed that 3 distinct lineages coexist in this lake. These results indicate that the geographical distribution and phylogenetic diversity of the genus Thioploca is greater than previously thought.
\end{abstract}

KEY WORDS: Sulfur-oxidizing bacteria $\cdot$ Freshwater lake $\cdot$ Sediment $\cdot$ Phylogeny

Resale or republication not permitted without written consent of the publisher

\section{INTRODUCTION}

Members of the genus Thioploca are uncultured sulfur-oxidizing bacteria that live in freshwater and brackish water sediments. They are visible to the naked eye as white filaments because of abundant elemental sulfur granules in their cells and their conspicuous morphology. Several multicellular filaments (trichomes) form bundles surrounded by a common sheath, and each trichome can glide independently within the common sheath. Early descriptions of Thioploca used the diameter of the trichome as a characteristic to discriminate species (Lauterborn 1907, Wislouch 1912, Maier 1984); most of the recent studies were performed on samples with trichome diameters of $\sim 4 \mu \mathrm{m}$ (Zemskaya et al. 2001, Kojima et al. 2003, 2006, Høgslund et al. 2010, Nemoto et al. 2011). Until recently, this genus also included marine species with much thicker trichomes, but a new independent candidate genus, 'Candidatus Marithioplo$\mathrm{Ca}^{\prime}$, has now been proposed to encompass these species (Salman et al. 2011).

Thioploca spp. have the ability to accumulate nitrate at high concentrations within their large cells; nitrate concentrations in the cells have been reported to be 2 or 3 orders of magnitude higher than ambient concentrations (Zemskaya et al. 2001, Kojima et al. 2007, Høgslund et al. 2010). This feature is more pronounced in closely related marine species in the genera Thiomargarita and 'Candidatus Marithioploca', among others, some of which are thought to greatly influence cycles of sulfur, nitrogen, and phosphorus in marine environments (Otte et al. 1999, Sayama 2001, Schulz \& Schulz 2005).

The first description of Thioploca species was of a population found in Lake Constance in Europe 
(Lauterborn 1907). Subsequently, populations were reported from Lake Erie and Lake Ontario in North America (Maier \& Murray 1965, Dermott \& Legner 2002), Lake Baikal in Siberia (Zemskaya et al. 2001), and Lake Biwa, Lake Ogawara, and Lake Okotanpe in Japan (Nishino et al. 1998, Kojima et al. 2006, Nemoto et al. 2011). These lakes are located in areas of mid-range to high latitudes in the northern hemisphere. The 16S rRNA gene sequences of Thioploca in these lakes are very closely related, even though they are separated geographically.

In the present study, we report the occurrence of the genus Thioploca in Lake Tonle Sap (Cambodia), which is located in a tropical monsoon climatic zone, and show results of phylogenetic analyses.

\section{MATERIALS AND METHODS}

Samples were obtained in May 2005, from the south basin of Lake Tonle Sap. This lake is characterized by a dramatic seasonal change of water level, and the samples were obtained in the season of shallow water depth. The sampling site, Site S3 $\left(12^{\circ} 33^{\prime} 57^{\prime \prime} \mathrm{N}, 104^{\circ} 22^{\prime} 10^{\prime \prime} \mathrm{E}\right.$; $0.4 \mathrm{~m}$ deep), corresponds to the site of a previous study (Ohtaka et al. 2010). At the sampling time, the $\mathrm{pH}$ and specific conductivity of surface water were 8.0 and $155 \mu \mathrm{S} \mathrm{cm} \mathrm{cm}^{-1}$ respectively (Ohtaka et al. 2010). The lake water was characterized by very low transparency $(0.02 \mathrm{~m})$. The sediment samples, taken using an Ekman-Birge grab sampler, were passed through a mesh with a pore size of $0.25 \mathrm{~mm}$. The retained filamentous materials were immediately fixed in $100 \%$ ethanol.

Before microscopic observation, the filamentous samples were soaked in distilled water for $30 \mathrm{~min}$ to replace the ethanol with water. The shapes of the filaments were observed, and the diameters of 200 trichomes were measured under an optical microscope (Axioplan 2, Zeiss).

Thioploca filaments (sheaths with trichomes) were carefully sorted from residual contaminating materials using tweezers and then rinsed with sterile water. DNA extraction was performed as described previously (Kojima et al. 2003). For Thioploca-specific polymerase chain reaction (PCR) amplification of the DNA region spanning from the 16S rRNA gene to the 23S rRNA gene, the primer FWTpl131F (Escherichia coli 16S rRNA positions 131-148; Salman et al. 2011) was used in combination with the probe GAM42a for Gammaproteobacteria (E. coli 23S rRNA positions 1027-1043; Manz et al. 1992) as a reverse primer. The following PCR conditions were used: $94^{\circ} \mathrm{C}$ for
$5 \mathrm{~min} ; 32$ cycles of $94^{\circ} \mathrm{C}$ for $1 \mathrm{~min}, 55^{\circ} \mathrm{C}$ for $1 \mathrm{~min}$, and $68^{\circ} \mathrm{C}$ for $3.5 \mathrm{~min}$; and $68^{\circ} \mathrm{C}$ for $7 \mathrm{~min}$. The PCR product was cloned using the TOPO TA cloning kit (Invitrogen). The regions including the cloned inserts were directly amplified from the cells by PCR, using the vector-specific primer pair M13F/M13R. Nucleotide sequences obtained from 12 clones were aligned with reference sequences from the public database using the ClustalX program (Thompson et al. 1997). Independent phylogenetic analyses were performed for each of the 3 gene regions (16S rRNA, 23S rRNA, and 16S-23S rRNA ITS) because the availability of reference sequences varied greatly between them. Neighbor-joining trees were constructed using MEGA4 software (Tamura et al. 2007). Bootstrap analysis was performed for 1000 replicates.

The nucleotide sequences obtained were submitted to GenBank under the accession numbers AB699673 to AB699684.

\section{RESULTS AND DISCUSSION}

The filaments analyzed in the present study were not abundant in the sediment of Lake Tonle Sap, and their occurrence was noticed only after sieving. Microscopic observation revealed the presence of trichomes with tapered ends, covered with a common sheath (Fig. 1). The trichome diameters ranged from 2.6 to $5.8 \mu \mathrm{m}$, with a mean of $3.9 \mu \mathrm{m}$ (Fig. 2). These morphological characteristics are similar to those of Thioploca species of other lakes. The sheaths had no constricted zone, which was observed in samples collected from Lake Biwa and Lake Constance (Kojima et al. 2003).

All of the 16S rRNA gene sequences obtained were related to published Thioploca sequences (Fig. 3).

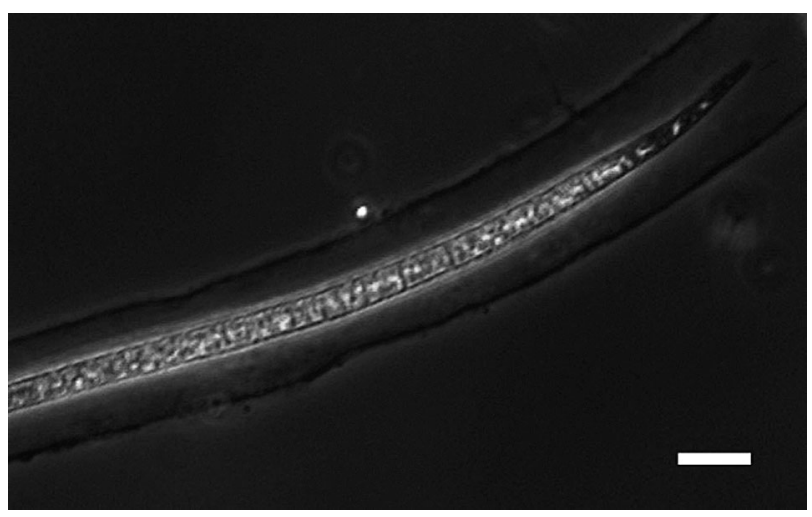

Fig. 1. Microphotograph of the tip of a trichome within a sheath. The tapered ends are characteristic for the genera Thioploca and Candidatus Marithioploca. Scale bar $=10 \mu \mathrm{m}$ 


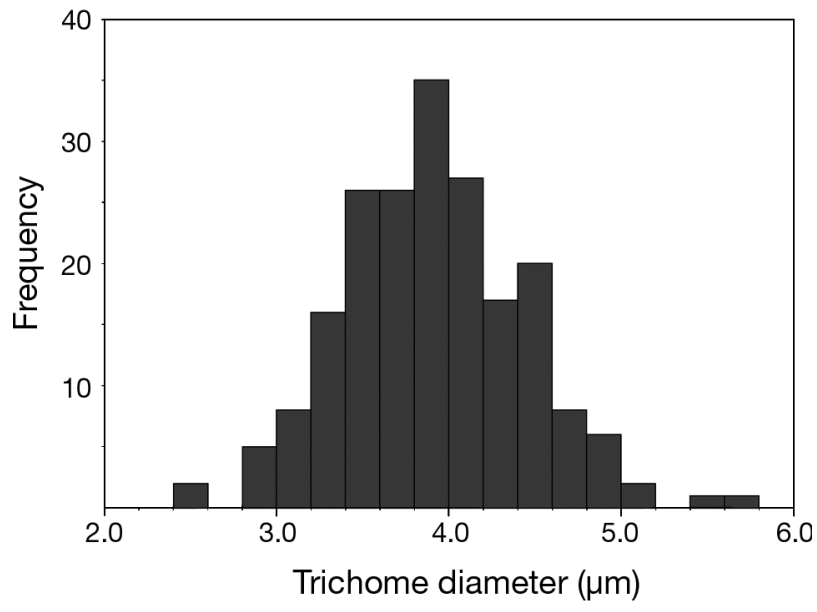

Fig. 2. Distribution of Thioploca trichome diameters $(n=200)$
Sequences of 9 clones were most closely related to a sequence from Grund Fjord, Denmark, and formed a distinctive cluster. Within this cluster of 9 clones, the 16S rRNA gene sequence identities were $>99 \%$. The sequence identities between these 9 clones and the other clones clustered with sequences from limnetic sediments, TS17 and TS80, were $\sim 98 \%$. The other clone, TS27, represented another independent lineage. The lowest identity, $97.4 \%$, was observed between TS27 and TS59. The results from the analysis of the ITS region were consistent with those of the 16S rRNA gene (Fig. 4), and similar results were also obtained in the analysis of the 23S rRNA gene (Fig. 5).

Based on morphological and phylogenetic characterizations, the filamentous organisms from Lake Tonle Sap were members of the genus Thioploca. According
Fig. 3. Neighbor-joining tree showing phylogenetic relationships between Thioploca obtained from Lake Tonle Sap and their closest relatives based on sequences of the 16S rRNA gene. The names of clones obtained in this study are prefixed with 'TS'. Genetic distances were calculated with nucleotides at positions 708-1406 (Escherichia coli numbering) using the maximum composite likelihood method, and gaps were treated as pairwise deletions. Boot strap values $>50 \%$ are shown. Scale bar is 0.02 nucleotide subsitutions per site

\section{- TS67 (AB699681) \\ TS50 (AB699678) \\ TS74 (AB699682) \\ TS21 (AB699676) \\ - TS59 (AB699680) \\ TS7 (AB699673) \\ 77 TS15 (AB699674) \\ TS30 (AB699677) \\ 71 TS52 (AB699679)}

Thioploca sp. DEN001 Grund Fjord (FR690997)

${ }_{92}$ Thioploca ingrica Randers Fjord (EU718071)

Thioploca ingrica Nissum Fjord (EU718069)

Thioploca sp. Lake Constance (AY115530)

Thioploca sp. Lake Baikal (DQ338566)

Thioploca sp. Lake Biwa (AF452892)

Thioploca sp. Lake Ogawara (AB263619)

68 Thioploca sp. Lake Okotanpe (AB645529)

100

Thioploca ingrica DEN002 Grund Fjord (FR690998)

Thioploca ingrica Hjarbæk Fjord (EU718070)

TS17 (AB699675)

Thioploca ingrica Randers Fjord (L40998)

— TS80 (AB699683)

TS27 (AB699684)

"Candidatus Marithrix sessilis" White Point filamentous bacterium (AY496953)

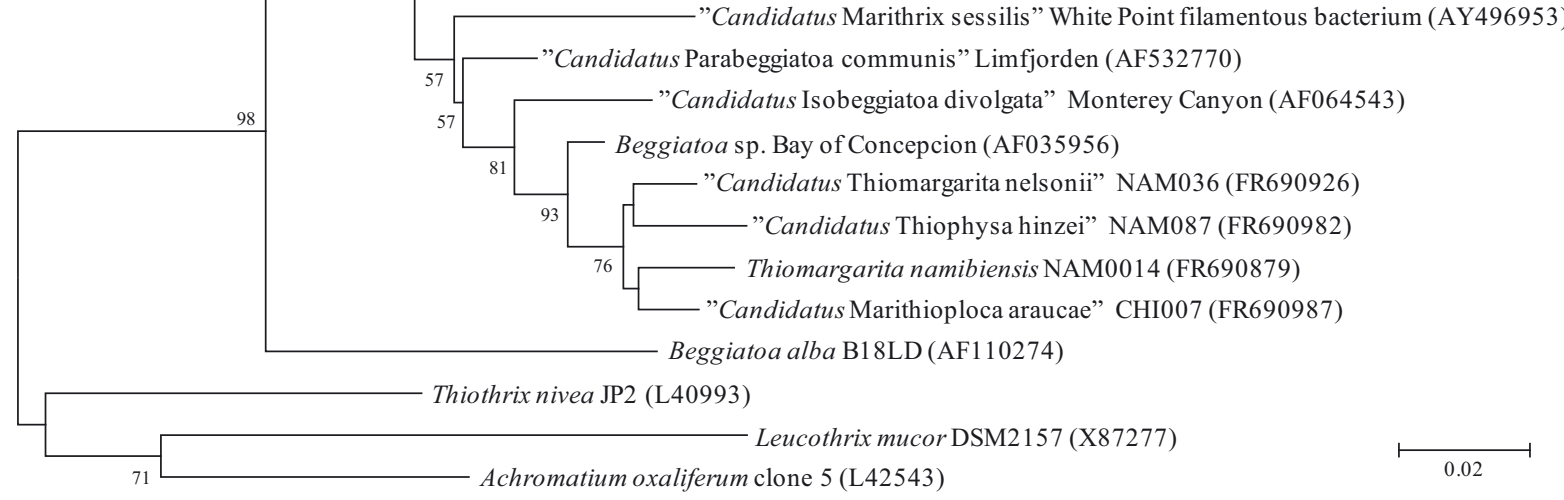




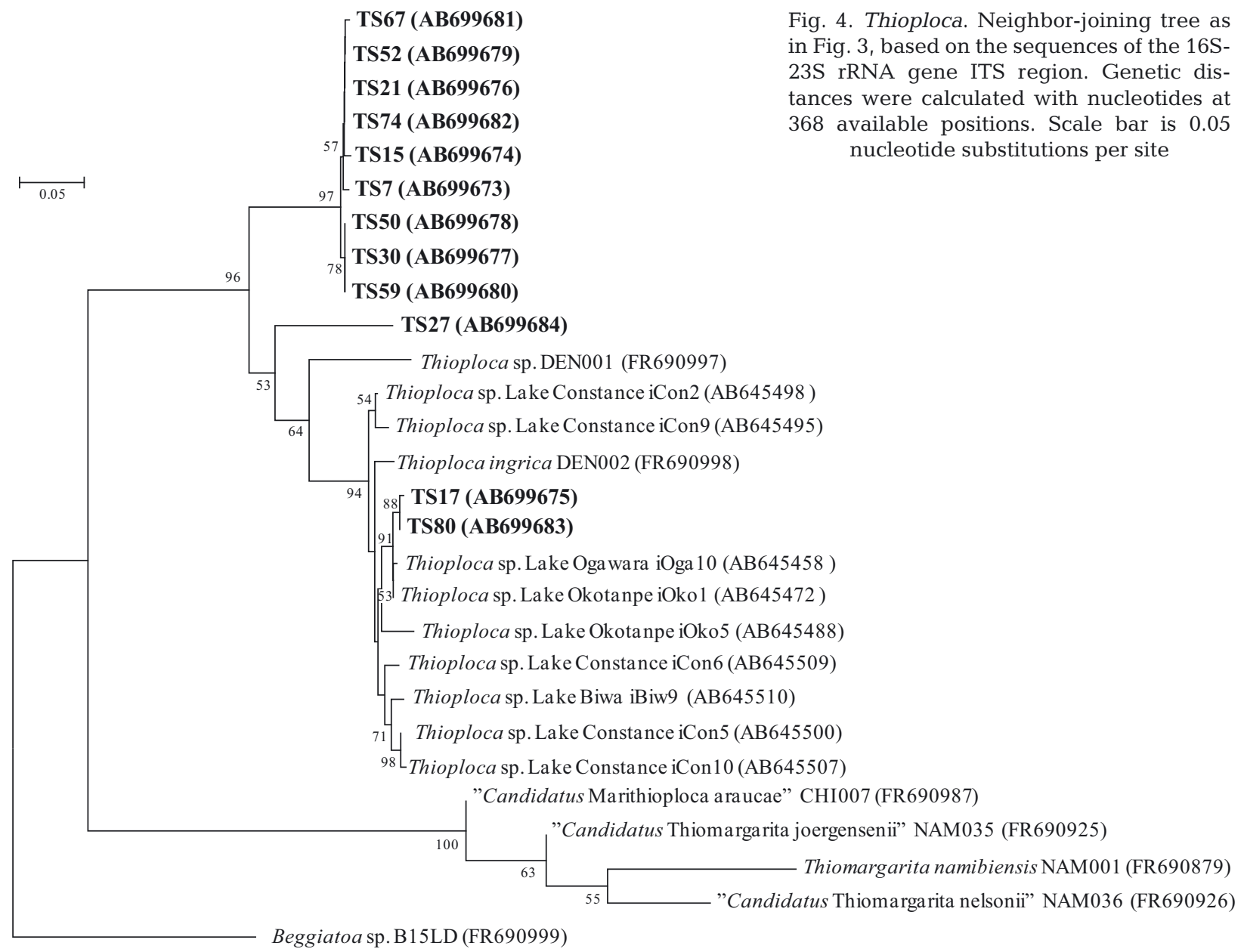

to the classification recently proposed (Salman et al. 2011), the present study is the first report of the genus Thioploca from a tropical area. To date, members of the genus Thioploca have been reported only from temperate and subarctic areas (Lauterborn 1907, Maier \& Murray 1965, Zemskaya et al. 2001, Dermott \& Legner 2002, Kojima et al. 2003, 2006, Høgslund et al. 2010, Nemoto et al. 2011). Among these lakes and fjords, Lake Biwa is located at the lowest latitude. In this lake, the 16S rRNA gene sequence of Thioploca was obtained from a sample taken from a profundal site, with temperatures ranging between 7 and $8^{\circ} \mathrm{C}$ throughout the year (Nishino et al. 1998, Kojima et al. 2003). In Lake Biwa, Thioploca was also detected in a site where sediment temperatures reached $30^{\circ} \mathrm{C}$ in summer but decreased to $7^{\circ} \mathrm{C}$ in winter. In contrast, the bottom water temperature of the sampling site in Lake Tonle Sap was $28.1^{\circ} \mathrm{C}$ in December 2004 and $30.9^{\circ} \mathrm{C}$ in May 2005 (Ohtaka et al. 2010).

The phylogenetic diversity within Thioploca of Lake Tonle Sap was consistently shown in the analyses of $16 \mathrm{~S}$ rRNA, 23S rRNA, and the ITS region. In other habitats, only a single 16S rRNA gene sequence of Thioploca has been reported from each lake (Kojima et al. 2003, 2006, Zemskaya et al. 2009, Nemoto et al. 2011), although the coexistence of different sequences was reported in a brackish fjord (Høgslund et al. 2010, Salman et al. 2011). In the present study, DNA was extracted from a clump of tangled filaments obtained by sieving bulk sediment. Therefore, there is no way to relate each sequence to morphology or localization in the sediment. Although further investigation is needed to evaluate the ecological significance of the coexistence observed, some sequences from Lake Tonle Sap were very closely related to those from other lakes and fjords, while others were distinct from those sequences. The former finding suggests that this lineage can sustain populations under a wide range of environmental conditions, whereas the latter result may indicate the presence of novel types of Thioploca specifically adapted to tropical lakes.

A previous study reported specific primers for the 16S rRNA gene of Thioploca (Kojima et al. 2003), but 
Fig. 5. Thioploca. Neighbor-joining tree as in Fig. 3, based on the sequences of the 23S rRNA gene. Genetic distances were calculated with nucleotides at positions 3-1026 (Escherichia coli numbering). Scale bar is 0.02 nucleotide subsitutions per site

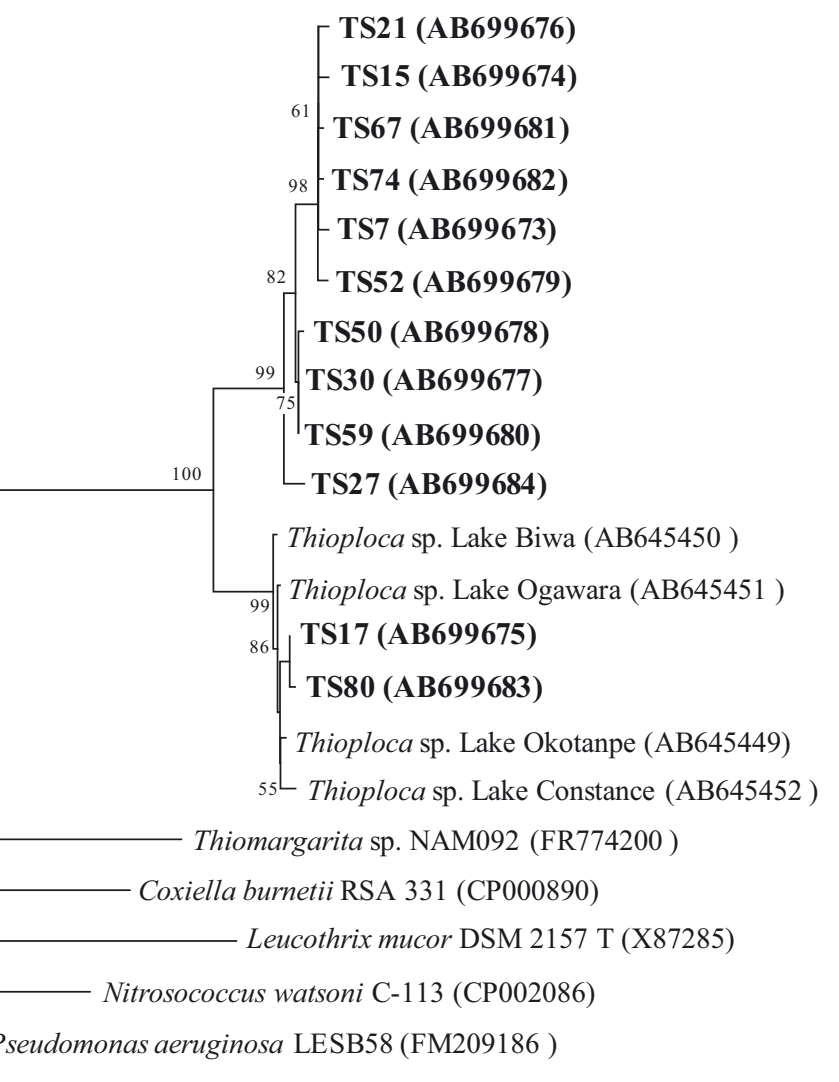

Burkholderia rhizoxinica HKI 454 (NC014722) there are some mismatches between these primers and sequences of Thioploca from Lake Tonle Sap. The primer used in the present study, FWTpl131F, may be more suitable for detection of diverse Thioploca, although its specificity is lower than those of the above-mentioned primers.

The present study shows that the geographical distribution and phylogenetic diversity of the genus Thioploca are greater than previously known. Further detailed analysis of the phylogenetic relationships and ecological characteristics of this genus in different habitats will provide more insights into Thioploca biogeography and the ecological interactions among coexisting strains.

Acknowledgements. The present study was funded by a Grant-in-Aid for International Scientific Research from the Japan Society for the Promotion of Science (15405004) and UNESCO and Japanese Funds-in-Trust Cooperation in the Field of Science (506RAS2009). We are most grateful to S. Tsukawaki of Kanazawa University, Japan, for encouragement throughout this study. We thank the Authority of the Protection and Management of Angkor and the Region of Siem Reap (APSARA), Cambodia, for supporting the field research. This study was also supported by grants from the Ministry of Education, Culture, Sports, Science, and Technology, Japan, to H.K. (19770008) and M.F. (22370005).

\section{LITERATURE CITED}

Dermott R, Legner M (2002) Dense mat-forming bacterium Thioploca ingrica (Beggiatoaceae) in eastern Lake Ontario: implications to the benthic food web. J Gt Lakes Res 28:688-697

> Høgslund S, Nielsen JL, Nielsen LP (2010) Distribution, ecology and molecular identification of Thioploca from Danish brackish water sediments. FEMS Microbiol Ecol 73:110-120

Kojima H, Teske A, Fukui M (2003) Morphological and phylogenetic characterizations of freshwater Thioploca species from Lake Biwa, Japan, and Lake Constance, Germany. Appl Environ Microbiol 69:390-398

Kojima H, Koizumi Y, Fukui M (2006) Community structure of bacteria associated with sheaths of freshwater and brackish Thioploca species. Microb Ecol 52:765-773

Kojima H, Nakajima T, Fukui M (2007) Carbon source utilization and accumulation of respiration-related substances by freshwater Thioploca species. FEMS Microbiol Ecol 59:23-31

Lauterborn R (1907) Eine neue Gattung der Schwefelbakterien (Thioploca schmidlei nov. gen. nov. spec.). Ber Dtsch Bot Ges 25:238-242

Maier S (1984) Description of Thioploca ingrica sp. nov., nom. rev. Int J Syst Bacteriol 34:344-345

Maier S, Murray RGE (1965) The fine structure of Thioploca ingrica and a comparison with Beggiatoa. Can J Microbiol 11:645-655

> Manz W, Amann R, Ludwig W, Wagner M, Schleifer KH (1992) Phylogenetic oligodeoxynucleotide probes for the 
major subclasses of Proteobacteria: problems and solutions. Syst Appl Microbiol 15:593-600

Nemoto F, Kojima H, Fukui M (2011) Diversity of freshwater Thioploca species and their specific association with filamentous bacteria of the phylum Chloroflexi. Microb Ecol 62:753-764

Nishino M, Fukui M, Nakajima T (1998) Dense mats of Thioploca, gliding filamentous sulfur-oxidizing bacteria in Lake Biwa, central Japan. Water Res 32:953-957

Ohtaka A, Watanabe R, Im S, Chhay R, Tsukawaki S (2010) Spatial and seasonal changes of net plankton and zoobenthos in Lake Tonle Sap, Cambodia. Limnology 11: 85-94

Otte S, Kuenen JG, Nielsen LP, Paerl HW and others (1999) Nitrogen, carbon, and sulfur metabolism in natural Thioploca samples. Appl Environ Microbiol 65: 3148-3157

Salman V, Amann R, Girnth AC, Polerecky L and others (2011) A single-cell sequencing approach to the classification of large, vacuolated sulfur bacteria. Syst Appl Microbiol 34:243-259

Sayama M (2001) Presence of nitrate-accumulating sulfur bacteria and their influence on nitrogen cycling in a shal-

Editorial responsibility: Rutger de Wit, Montpellier, France low coastal marine sediment. Appl Environ Microbiol 67: 3481-3487

Schulz HN, Schulz HD (2005) Large sulfur bacteria and the formation of phosphorite. Science 307:416-418

Tamura K, Dudley J, Nei M, Kumar S (2007) MEGA4: molecular evolutionary genetics analysis (MEGA) software version 4.0. Mol Biol Evol 24:1596-1599

Thompson JD, Gibson TJ, Plewniak F, Jeanmougin F, Higgins DG (1997) The CLUSTAL_X windows interface: flexible strategies for multiple sequence alignment aided by quality analysis tools. Nucleic Acids Res 25: 4876-4882

Wislouch SM (1912) Thioploca ingrica nov. sp. Ber Dtsch Bot Ges 30:470-473

Zemskaya TI, Namsaraev BB, Dul'tseva NM, Khanaeva TA and others (2001) Ecophysiological characteristics of the mat-forming bacterium Thioploca in bottom sediments of the Frolikha Bay, northern Baikal. Microbiology 70 : 335-341

Zemskaya TI, Chernitsyna SM, Dul'tseva NM, Sergeeva VN, Pogodaeva TV, Namsaraev BB (2009) Colorless sulfur bacteria Thioploca from different sites in Lake Baikal. Microbiology 78:117-124

Submitted: February 29, 2012; Accepted: May 29, 2012

Proofs received from author(s): June 26, 2012 